\title{
EFEKTIVITAS AKUPUNKTUR “GI" TERHADAP PENGOBATAN STRES PADA PASIEN DI KLINIK AKUPUNKTUR SUKAMENAK DAN UPT LAYANAN KESEHATAN BUMI MEDIKA GANESA ITB
}

\author{
Risna Agustina, Andreanus A. Soemardji \\ Clinical Pharmacy and Community Master Program, \\ School of Pharmacy Institut Teknologi Bandung (ITB) \\ Jl. Ganesha no. 10, Bandung 40132, Indonesia \\ *Email : aaisyahrisna@yahoo.com
}

\begin{abstract}
The effectiveness of "GI" acupuncture to treat patients with stress had been done on the respondents who did acupuncture therapy at the Acupuncture Clinic Sukamenak and Clinic Bumi Medika Ganesha where "GI" acupuncture is practiced. The purpose of this study is to know effectiveness of "GI" Acupuncture to decrease stress levels in people with stress, as well as to strengthen usefulness and position of "GI" Acupuncture in health system as a complementary therapy. Methode of this study is concurrent observational of the qualitative and quantitative done for \pm 4 months by interviews with the main parameters of Stress Scale. Analysis of therapeutic effect of "GI" Acupuncture against people with stress can be seen through decreased stress score on the respondents that happen after the routinely perform acupuncture therapy and also see the influence of age, and sex to the decrease score stress. Results of the study showed that there was a significant correlation $(r=-0.998)$ between the decrease stress score and number of "GI" acupuncture therapy, obtained negative values indicate a relationship in which the greater number of "GI" acupuncture therapy was then the score stress will decrease. Moreover, this study proves the influence of gender on the effectiveness of "GI" acupuncture therapy. It can be concluded that "GI" Acupuncture role in the suppression of the symptoms of stress, accounted for prospectively as a complementary or alternative therapy for patients with stress.
\end{abstract}

Key Word: "GI” Acupuncture, stress, effectiveness.

\begin{abstract}
ABSTRAK
Penelitian mengenai pengaruh akupunktur "GI" pada pengobatan stres telah dilakukan pada pasien stres yang melakukan terapi akupunktur di Klinik Akupunktur Sukamenak dan UPT Layanan Kesehatan Bumi Medika Ganesa. Tujuan dari penelitian ini adalah untuk mengetahui efektivitas Akupunktur "GI" terhadap penurunan tingkat stres pada pasien, serta untuk memperkuat kegunaan dan posisi akupunktur "GI" dalam sistem kesehatan sebagai terapi komplementer. Penelitian ini merupakan studi observasional konkuren secara kualitatif dan kuantitatif yang dilakukan selama 3 bulan melalui wawancara dengan parameter utama skala stres. Analisis pengaruh terapi Akupunktur "GI" terhadap pasien stres dapat diamati melalui penurunan skor stres pada responden yang rutin melakukan terapi akupunktur dan juga pengaruh usia, dan jenis kelamin terhadap penurunan skor stres. Hasil penelitian menunjukkan bahwa ada hubungan bermakna $(r=-0,998)$ antara penurunan skor
\end{abstract}


stres dengan jumlah terapi akupunktur "GI", adanya hubungan jumlah terapi akupunktur "GI" yang dilakukan dengan penurunan skor stres. Selain itu, penelitian ini membuktikan adanya pengaruh jenis kelamin terhadap efektivitas terapi akupunktur "GI". Dapat disimpulkan bahwa terapi akupunktur "GI" berperan dalam penekanan gejala stres, prospektif sebagai terapi alternatif ataupun komplementer bagi penderita stres.

Kata kunci : Akupunktur “GI”, stres, efektivitas

\section{PENDAHULUAN}

Salah satu metode pengobatan tradisional adalah akupunktur yang berasal dari Cina dan telah dipraktekkan selama kurang lebih 2500 tahun. Terapi akupuntur didasarkan pada kepercayaan bahwa mahluk hidup memiliki energi vital, yang disebut "qi". Energi ini bersirkulasi melewati 12 energi tak terlihat dan diketahui sebagai garis meridian pada tubuh. Ketidakseimbangan pada aliran "qi" dipercaya sebagai penyebab penyakit ${ }^{1}$ Akupunktur berkembang menjadi berbagai metode penusukan, seperti teknik rangsang listrik, dan lain-lain. Penelitian ini berfokus pada akupunktur GI yang merupakan salah satu metode baru. Akupunktur "GI" merupakan salah satu teknik akupunktur yang dikembangkan berdasarkan teknik akupunktur yang telah ada sebelumnya dan didasarkan pada penggabungan metode pengobatan tradisional Timur dan ilmu kedokteran Barat. Teknik akupuntur ini akan menghasilkan metode lebih sederhana dengan karakteristik titik penusukan yang lebih sedikit namun lebih dalam $^{2}$.

Stres adalah reaksi/respons tubuh terhadap stresor psikososial (tekanan mental / beban kehidupan). Stres merupakan konteks yang menjembatani pertemuan antara individu dengan stimulus yang membuat stres dan semua sebagai suatu sistem ${ }^{3}$. Kebanyakan penyakit diketahui memiliki kaitan dengan stres. Stres merupakan penyebab dari 70 hingga $90 \%$ keadaan yang disebut penyakit ${ }^{4}$.
Menurut WHO, akupunktur (akupresur) jauh lebih efektif dibandingkan psikoterapi dalam pengobatan sindrom stres. Penelitian ini dilakukan secara konkuren di Klinik Akupunktur Sukamenak dan Bumi Medika Ganesa selama kurang lebih 3 bulan melalui pengamatan langsung dan wawancara pasien. Penelitian ini bertujuan membuktikan dan mengukur efektivitas terapi akupunktur terutama terapi akupunktur "GI" terhadap stres. Efektivitas metode tersebut dapat diketahui dengan adanya penurunan skor stres sebelum dan sesudah dilakukan terapi serta peningkatan performa pasien. Selain itu diharapkan hasil penelitian ini dapat memperkuat kegunaan dan posisi akupunktur "GI" dalam sistem kesehatan sebagai terapi komplementer ataupun terapi alternatif ${ }^{5}$.

\section{METODOLOGI PENELITIAN}

Penelitian ini merupakan suatu studi observasional konkuren secara kualitatif dan kuantitatif. Penelitian dilakukan dengan mengamati adanya penurunan tingkat stres pada pasien stres sebelum dan sesudah dilakukan terapi akupunktur serta wawancara melalui pengisian kuisioner yang berisi pertanyaan terkait dengan perilaku atau kondisi yang dialami para pasien stres. 


\section{DESAIN PENELITIAN}

\section{Kriteria Pasien}

Kriteria inklusi sampel pada penelitian ini adalah pasien pria dan wanita, dewasa dan lansia, dengan diagnosis stres, rutin melakukan terapi akupunktur "GI" atau minimal telah menjalani terapi sebanyak delapan kali dengan frekuensi 2 kali seminggu. Kriteria eksklusi dalam penelitian ini adalah pasien pria dan wanita yang diagnosis utamanya bukan stres, pasien yang tidak rutin melakukan terapi akupunktur "GI" atau menjalani terapi kurang dari delapan kali, dan pasien yang usianya termasuk dalam kategori anak.

\section{Tempat Penelitian}

Penelitian ini dilaksanakan di dua tempat berbeda yaitu di Klinik Akupunktur Sukamenak dan Balai Pengobatan Bumi Medika Ganesa.

\section{Data dan Sumber Data}

Pengambilan data dilakukan melalui wawancara dari kuisioner stres yang dapat menggambarkan keefektifan terapi akupunktur terhadap pasien stress. Pengukuran tingkatan stres pada pasien menggunakan Depression Anxiety Stress Scale 42 (DASS 42) ${ }^{6}$. DASS adalah seperangkat skala subyektif yang dibentuk untuk mengukur status emosional negatif dari depresi, kecemasan dan stres. Kuisioner yang digunakan tentunya yang sudah disesuaikan dengan kondisi pasien di Indonesia.

\section{Pengelompokan Data}

Data dikelompokkan berdasarkan sub variabel. Dari kuisioner yang dibuat dicatat semua variabel yang akan diamati. Dari hasil kuisioner tersebut, variabel dikumpulkan kemudian dibuat tabulasi seperti jenis kelamin, usia, tingkatan stres, riwayat atau penyebab munculnya stres, muncul atau tidaknya efek samping selama atau sesudah terapi akupunktur.

\section{Pengolahan Data}

Hipotesis 0 yaitu tidak adanya perbedaan skor stres sebelum dan sesudah terapi akupunktur di uji dengan uji Friedman karena diasumsikan bahwa sampel yang diuji berpasangan dan datanya merupakan data ordinal. Untuk uji korelasi menggunakan Pearson yang merupakan uji lanjutan dari Friedman. Semua data yang terkumpul diolah, dianalisis dengan SPSS 17. Pengujian tidak bermakna apabila nilai $\mathrm{p}>0,05$, sedangkan bila nilai $\mathrm{p} \leq 0,05$ pengujian bermakna dan pengujian sangat bermakna bila nilai $\mathrm{p} \leq 0,01$. Kemaknaan dipilih pada $\alpha=5 \%^{7}$.

\section{HASIL PENELITIAN DAN PEMBAHASAN}

\section{Data Karakteristik Responden Akupunktur}

Jumlah responden yang masuk dalam kriteria inklusi dalam penelitian ini sejumlah 63 orang dari 89 pasien pada periode November-Januari 2013. Subyek penelitian ini terdiri dari 16 orang $(26,15 \%)$ yang menjalani terapi akupunktur "GI" di UPT Bumi Medika Ghanesa ITB dan 47 orang $(73.85 \%)$ menjalani terapi di Klinik Akupunktur Sukamenak. Data tersebut kemudian didistribusikan berdasarkan jenis kelamin, tingkatan usia, riwayat stres, tingkatan stres, dan besarnya penurunan stres skor. Data demografi subjek penelitian dipaparkan dalam tabel 1 . 
Tabel 1 Karakteristik Responden Stres Berdasarkan Usia dan Jenis Kelamin

\begin{tabular}{ccccccc}
\hline Kategori & Usia & \multicolumn{2}{c}{ Laki - laki } & \multicolumn{2}{c}{ Wanita } & JUMLAH \\
\cline { 3 - 6 } & (tahun) & Jumlah & $\%$ & Jumlah & $\%$ & $\%$ \\
\hline Dewasa & $18-40$ & 0 & 0 & 15 & 23,81 & 23,81 \\
& $41-65$ & 6 & 9,52 & 35 & 55,56 & 65,08 \\
Geriatri & $>65$ & 3 & 4,76 & 4 & 6,35 & 11,11 \\
\hline Total & & 9 & 14,28 & 54 & 85,72 & 100 \\
\hline
\end{tabular}

Melalui Tabel 1 dapat dilihat bahwa kasus stres pada laki-laki banyak terjadi pada usia 41-65 tahun yaitu sebanyak $9,52 \%$ (6 kasus) sedangkan pada wanita dengan kasus stres banyak terjadi pada usia 41-65 tahun yaitu sebesar $55,56 \%$ (35 kasus). Tingkat stres antara laki-laki dan perempuan berbeda secara signifikan dengan tingkat stres perempuan lebih tinggi di bandingkan dengan lakilaki. Hal ini sesuai dengan hasil penelitian Licitra-Klecker dan Waas ${ }^{8}$ yang menyatakan bahwa perempuan cenderung lebih tinggi tingkat stresnya dibandingkan laki-laki karena perempuan cenderung lebih merasa tertekan terhadap hal-hal yang dialaminya sehari-hari, sedangkan laki-laki tidak menganggap hal-hal tersebut sebagai sesuatu yang menekan. Stres pada wanita usia 41-65 tahun disebabkan oleh adanya masa menopause, dan kekhawatiran pada kehidupan bertambah karena menopause.

\section{Data Klinik Berupa Gejala Pada Responden}

Gejala stres sangatlah beragam dan memiliki variasi yang berbeda pada tiap individu. Gejala ini berlangsung kronis dan tidak dapat diprediksi sehingga mengganggu aktivitas harian yang memiliki dampak terhadap kualitas hidup responden yang menurun. Secara umum gejala yang sering dikeluhkan yaitu pusing, susah tidur, maag, pola makan yang tak teratur, cepat merasa lelah, yang pada akhirnya berhujung pada psikosomatis. Berikut adalah data klinik hasil wawancara responden yang menunjukkan gejala Stres.

Tabel 2 Karakteristik dan Presentase Gejala Stres Responden ( $\mathrm{n}=63)$

\begin{tabular}{lc}
\hline \multicolumn{1}{c}{ Gejala/ Keluhan } & Persentase Gejala / Keluhan \\
\hline Gangguan Metabolik Sistemik & 73,46 \\
Gangguan Pola Tidur dan Nyeri Kepala & 97,65 \\
Gangguan Imun Sistem & 38,10 \\
Gangguan Sistem Pencernaan & 88,37 \\
Gangguan Hormonal & 90,33 \\
Gangguan Muskoskeletal & 73,02 \\
\hline
\end{tabular}

Tabel 2 menunjukkan bahwa gangguan tidur dan nyeri kepala merupakan gejala yang mendominasi seluruh pasien stres yaitu sebesar $97,65 \%$.
Gangguan tidur berhubungan dengan meningkatnya dopamin di hipokampus, daerah yang berhubungan dengan emosi dan memori. Dopamin berfungsi 
mengatur nafsu makan dan rasa mual, dengan meningkatnya dopamin nafsu makan akan berkurang disebabkan meningkatnya rasa mual. Emosi dapat mempengaruhi berbagai sistem fisiologis, termasuk sistem kardiovaskular, saraf, kekebalan, dan hormonal. Sistem-sistem itu menunjukkan efek stres dan kondisi mental serta emosi terhadap elektrofisiologi tubuh.

Sebanyak 90,33\% responden mengalami gangguan hormonal yang disebabkan oleh stres. Bila seorang dalam keadaan depresi dapat menyebabkan kadar hormon stres menjadi tinggi dan mengakibatkan kepadatan tulang berkurang seperti orang yang berusia 70 tahun, sehinnga lebih rentan terhadap patah tulang. Emosi akan memicu reaksi tubuh yang akhirnya dapat menimbulkan kerusakan jangka panjang ${ }^{9}$.

$$
\text { Gangguan pada sistem }
$$

pencernaan dialami oleh $88,37 \%$ responden. Penyakit pencernaan timbul sebagai akibat dari mengkonsumsi makanan yang berlebihan atau pola makan yang tak teratur ${ }^{9}$.

Gangguan pada metabolik sistemik yang dialami $73,46 \%$ responden dapat disebabkan oleh kehidupan di masyarakat yang sarat akan tekanan, dan ketika berada dalam situasi yang teramat stres, maka hormon noradrenalin akan diproduksi oleh tubuh ${ }^{4}$.

Gangguan pada sistem imun pada $38,10 \%$ responden yang merupakan efek dari pikiran yang memiliki dampak terhadap kekebalan tubuh dapat disebabkan adanya sistem komunikasi dua arah yang banyak dan rumit, yang menghubungkan pikiran, sistem kekebalan, dan semua sistem lainnya, sebuah cara yang dapat dipakai oleh emosi, harapan dan ketakutan, untuk mempengaruhi kemampuan tubuh dalam mempertahankan diri. ${ }^{10}$.

Kerja dan efek akupunktur yaitu menggunakan efek umpan balik biologi, dimana seseorang dilatih untuk memperbaiki kesehatan dengan menggunakan sinyal-sinyal dari tubuh sendiri. Para terapis fisik menggunakan umpan balik biologis untuk membantu para responden stroke mendapatkan kembali gerakan pada otot-otot yang lumpuh. Para psikolog menggunakannya untuk membantu klien yang tegang dan cemas agar dapat belajar rileks.

\section{Analisis Efektivitas Akupunktur "GI" Terhadap Kasus Stres}

Sasaran terapi stres adalah untuk mengurangi tingkat stres responden dengan cara menurunkan gejala atau keluhan yang timbul dan meningkatkan fungsi tanpa adanya polifarmasi. Melalui pertimbangan efek samping jangka panjang yang disebabkan oleh obat, maka akupunktur merupakan terapi alternatif yang dapat digunakan untuk mengurangi gejala yang diakibatkan dari stres.

Untuk mengamati efektivitas terapi akupunktur "GI", pemantauan kondisi responden dilakukan secara kualitatif melalui skoring DASS (Depression Anxiety Stress Scale) yang telah diakui secara internasional dan dianggap efektif pada penelitian stres ${ }^{6}$. DASS sering digunakan pada studi yang berkaitan dengan stres dan telah digunakan pada lebih dari 100 artikel. Metode skoring DASS yang digunakan pada penelitian ini disesuaikan dengan kondisi responden di Indonesia yang mencakup 3 subvariabel, yaitu fisik, emosi/psikologis, dan perilaku. Jumlah skor dari pernyataan tersebut, dikaitkan dengan efektivitas terapi dimana 0 adalah normal, 1-29 stres positif, 30-59 ringan, 60-89 sedang, > 90 berat.

\section{Analisis Efektivitas Akupunktur 'GI' Terhadap Stres Secara Umum \\ Efektivitas akupunktur "GI"} secara umum pada penelitian ini diukur dengan menghitung besar penurunan skor kuisioner stres yang melibatkan 63 responden. Penelitian ini dilakukan dengan skoring kuisioner stres pada saat 
responden sebelum mendapatkan terapi akupunktur "GI" dan setelah responden mendapatkan terapi ke $2,4,6,8,10,12$, 14, 16, 18 kali. Hipotesis nol yang diajukan adalah bahwa tidak terdapat perbedaan yang bermakna antara penurunan skor stres dengan jumlah terapi akupunktur. Untuk dapat melihat perkembangan penurunan skor stres terhadap jumlah terapi, berikut tabel ratarata skor stres terhadap jumlah terapi.

Tabel 3. Rata-Rata Skor Stres Responden Menggunakan Terapi Akupunktur "GI"

\begin{tabular}{|c|c|c|c|c|c|c|c|c|c|}
\hline \multirow[b]{3}{*}{$\begin{array}{l}\text { Akupunktur } \\
\text { ke- }\end{array}$} & \multicolumn{9}{|c|}{$\begin{array}{c}\text { Kelompok Responden } \\
\end{array}$} \\
\hline & \multicolumn{2}{|c|}{ Stres Positif } & \multicolumn{2}{|c|}{ Stres Ringan } & \multicolumn{2}{|c|}{ Stres Sedang } & \multicolumn{2}{|c|}{ Stres Berat } & \multirow{2}{*}{$\begin{array}{c}\text { Rata-rata } \\
\text { skor stres } \\
\text { keseluruhan } \\
(\mathrm{n}=63)\end{array}$} \\
\hline & $\begin{array}{l}\text { Pria } \\
(\mathrm{n}=2)\end{array}$ & $\begin{array}{l}\text { Wanita } \\
(\mathrm{n}=10)\end{array}$ & $\begin{array}{l}\text { Pria } \\
(\mathrm{n}=5)\end{array}$ & $\begin{array}{l}\text { Wanita } \\
(\mathrm{n}=22)\end{array}$ & $\begin{array}{l}\text { Pria } \\
(n=2)\end{array}$ & $\begin{array}{l}\text { Wanita } \\
(\mathrm{n}=13)\end{array}$ & $\begin{array}{c}\text { Pria } \\
(\mathrm{n}=0)\end{array}$ & $\begin{array}{l}\text { Wanita } \\
(\mathrm{n}=10)\end{array}$ & \\
\hline \multirow[t]{2}{*}{0} & $20 \pm$ & $20,8 \pm$ & $41,8 \pm$ & $48,5 \pm$ & $73,5 \pm$ & $76,6 \pm$ & 0 & $106,4 \pm$ & $58,5 \pm 30,0$ \\
\hline & 5,7 & 5,0 & 10,9 & 13,6 & 12,0 & 10,5 & & 14,8 & \\
\hline \multirow[t]{2}{*}{2} & $20 \pm$ & $20,8 \pm$ & $41,3 \pm$ & $42,4 \pm$ & $71 \pm$ & $65,3 \pm$ & 0 & $97,3 \pm$ & $52,5 \pm 27,5$ \\
\hline & 5,7 & 5,0 & 11,2 & 11,7 & 15,6 & 14,1 & & 17,4 & \\
\hline \multirow[t]{2}{*}{4} & $17 \pm$ & $19 \pm$ & $36,5 \pm$ & $38,6 \pm$ & $62 \pm$ & $57,1 \pm$ & 0 & $82,3 \pm 1$ & $46,2 \pm 23,7$ \\
\hline & 1,4 & & 1,7 & 12,7 & 9,9 & 17,1 & & 2,4 & \\
\hline \multirow[t]{2}{*}{6} & $14 \pm$ & $16,7 \pm$ & $32,75 \pm$ & $32,7 \pm$ & $52,5 \pm$ & $49,5 \pm$ & 0 & $80,5 \pm$ & $41,3 \pm 23,1$ \\
\hline & 5,7 & 6,1 & 5,7 & 11,6 & 2,1 & 13,8 & & 12,9 & \\
\hline 8 & $\begin{array}{c}12 \pm \\
2,8\end{array}$ & $\begin{array}{c}14,5 \pm \\
6,0\end{array}$ & $\begin{array}{c}29,5 \pm \\
2,1\end{array}$ & $\begin{array}{c}27,7 \pm \\
9,5\end{array}$ & $\begin{array}{l}35 \pm \\
15,6\end{array}$ & $\begin{array}{c}43,8 \pm \\
15,8\end{array}$ & 0 & $\begin{array}{c}67,6 \pm \\
9,2\end{array}$ & $35,1 \pm 19,9$ \\
\hline 10 & $\begin{array}{c}12 \pm \\
2,8\end{array}$ & $\begin{array}{c}13,4 \pm \\
5,9\end{array}$ & $\begin{array}{c}25 \pm \\
5,0\end{array}$ & $\begin{array}{c}24,4 \pm \\
8,8\end{array}$ & $\begin{array}{c}31,5 \pm \\
10,7\end{array}$ & $\begin{array}{c}39,9 \pm \\
15,3\end{array}$ & 0 & $\begin{array}{c}54,1 \pm \\
7,6\end{array}$ & $30,4 \pm 16,4$ \\
\hline 12 & $\begin{array}{c}12 \pm \\
2,8\end{array}$ & $\begin{array}{c}11,7 \pm \\
5,5\end{array}$ & $\begin{array}{l}24,7 \\
\pm 5,2\end{array}$ & $\begin{array}{l}17,7 \pm \\
7,2\end{array}$ & $\begin{array}{c}31,5 \pm \\
3,6\end{array}$ & $\begin{array}{c}32,9 \pm \\
18,6\end{array}$ & 0 & $\begin{array}{l}38, \pm \\
12,5\end{array}$ & $23,9 \pm 14,4$ \\
\hline 14 & $\begin{array}{c}5,5 \pm \\
3,5\end{array}$ & $\begin{array}{c}9,6 \pm \\
3,8\end{array}$ & $\begin{array}{c}20,3 \pm \\
8,7\end{array}$ & $\begin{array}{c}15,1 \pm \\
7,3\end{array}$ & $\begin{array}{c}26,5 \pm \\
3,5\end{array}$ & $\begin{array}{c}24,3 \pm \\
10,2\end{array}$ & 0 & $\begin{array}{c}32,3 \pm \\
9,5\end{array}$ & $19,2 \pm 10,9$ \\
\hline 16 & $\begin{array}{c}5,5 \pm \\
3,5\end{array}$ & $\begin{array}{c}7,3 \pm \\
3,6\end{array}$ & $\begin{array}{c}12,8 \pm \\
5,0\end{array}$ & $\begin{array}{c}10 \pm \\
5,0\end{array}$ & $\begin{array}{c}26,5 \pm \\
3,5\end{array}$ & $\begin{array}{c}17,9 \pm \\
7,4\end{array}$ & 0 & $\begin{array}{c}21,8 \pm \\
8,9\end{array}$ & $13,3 \pm 8,2$ \\
\hline
\end{tabular}

Tabel 3 menunjukkan rentang nilai skor rata-rata pada kondisi awal pada pasien pria, pada kategori stres positif adalah sebesar 16 sampai 24 dari skor maksimum 29. Stres ringan skor 32-48 dari skor maksimum 59, stres sedang berada pada kisaran skor 65-83 dari skor maksimum 89. Rentang skor yang cenderung lebar ini mengacu pada berat dan lamanya keluhan gejala yang dirasakan responden. Pada wanita terlihat rentang yang lebih besar dibandingkan dengan pria, untuk kategori stres positif 16-28, ringan 32-72, sedang 64-100, dan berat sebesar 90-118. Hal ini menunjukkan bahwa wanita cenderung memiliki faktor resiko yang lebih besar terhadap stres.
Untuk mengamati efektivitas akupunktur "GI" terhadap penekanan gejala stres berdasarkan jumlah terapi dilakukan uji statistik dan dihasilkan nilai signifikansi $\mathrm{p}=<0,05 \%$. yang berarti hipotesis nol (H0) ditolak, bahwa ada perbedaan bermakna antara antara sebelum terapi dengan setelah terapi ke 2, 4, 6, hingga ke 18 dengan penurunan skor stres. Untuk mendukung hasil statistik dilakukan uji korelasi dan regresi, berdasarkan penelitian yang telah dilakukan diperoleh nilai korelasi untuk hubungan jumlah terapi akupunktur dengan penurunan skor stres yaitu hubungan antar variabel memiliki hubungan kuat dimana diperoleh nilai $\mathrm{r}=$ - 0,998 dan nilai signifikan sebesar 0,000, 
tanda negatif memiliki arti bahwa adanya perbandingan terbalik antara skor stres dengan jumlah akupunktur yaitu semakin banyak dilakukannya terapi akupunktur maka skor stres akan semakin menurun, nilai $\mathrm{r}=0,998$ menunjukkan adanya hubungan yang kuat antara jumlah akupunktur dengan stres, karena nilai jika nilai $r$ semakin mendekati 1 maka hubungannya akan semakin kuat. Pada umumnya pasien akan mencapai titik efektif terapi akupunktur setelah itu kondisinya akan tetap meski terus melakukan terapi akupunktur "GI" secara rutin. Pasien yang terus melakukan terapi akupunktur hanya untuk menjaga kondisi tubuhnya. Dari data diatas dapat disimpulkan secara statistik terdapat perubahan yang lebih baik dan bermakna pada setiap pemantauan rentang 2 kali terapi. Secara umum pasien merasakan adanya perbaikan pada kondisi tubuh setelah menjalani terapi akupunktur.

\section{Evaluasi Pengukuran Skor Stres}

Evaluasi ini bertujuan untuk mengamati efektivitas akupunktur "GI" ditinjau dari parameter skor stres yang diukur dengan hasil kuisioner wawancara selama mendapatkan terapi. Kuisioner terdiri dari 42 pertanyaan yang mengukur gejala fisik, psikologis dan fungsi sosial dari munculnya stres, sehingga didapatkan gambaran penyebab munculnya stres dan sumber stres pada responden. Kemudian dilakukannya analisis hubungan antara pengukuran penurunan skor stres dengan jumlah akupunktur melalui beberapa parameter, yaitu jenis kelamin, usia dan latihan fisik yakni olahraga. Berikut merupakan gambaran umum rata-rata skor stres dengan jumlah terapi.

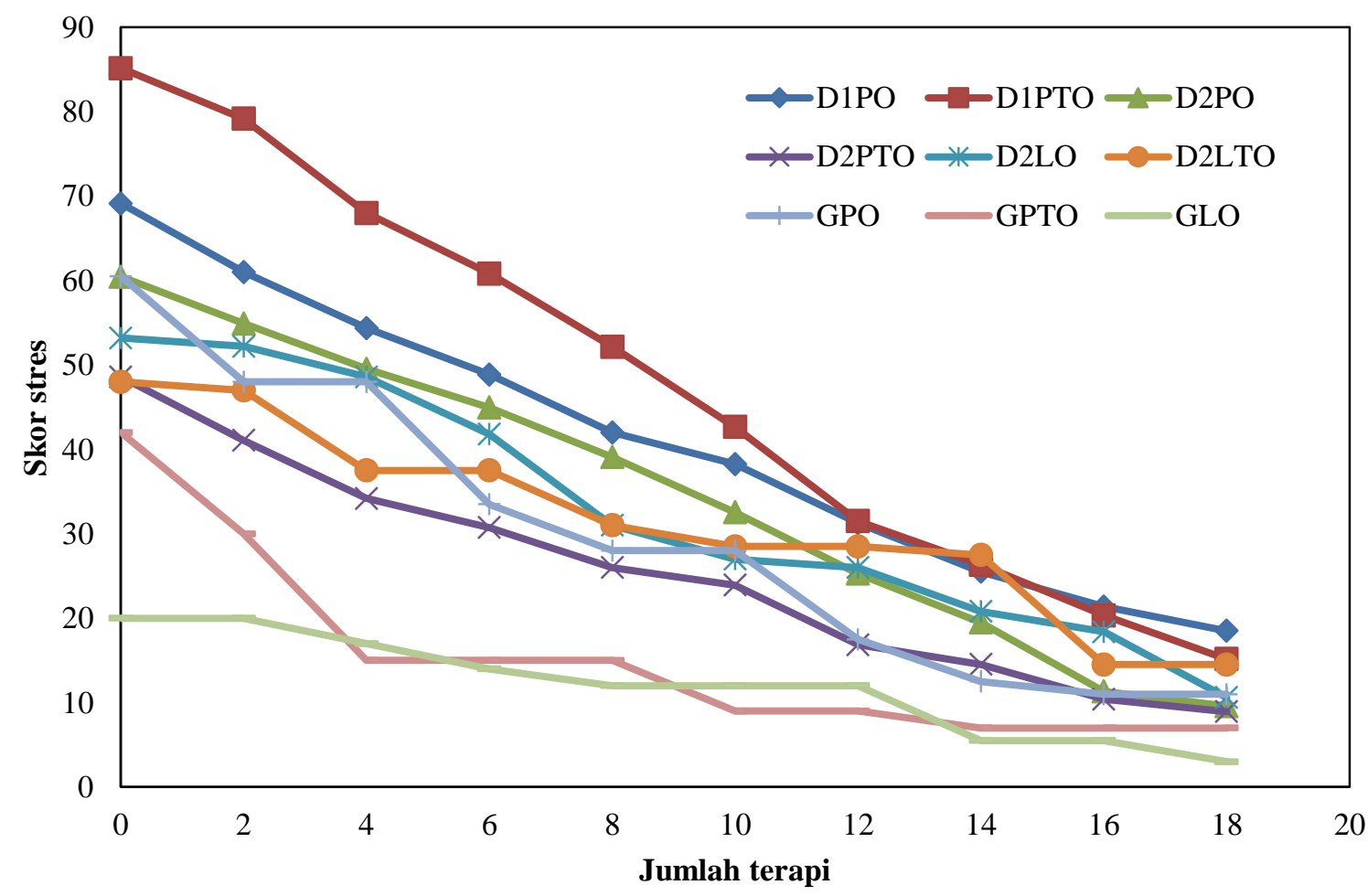

Gambar 1 Rata-rata Skor Stres Terhadap jumlah Terapi

\begin{tabular}{|c|c|c|}
\hline Ceterangan : & D1:Usia Dewasa 18 - 40 tahun & D2:Usia Dewasa 41 - 65 tahun \\
\hline & $\begin{array}{l}\mathrm{G}: \text { :Geriatri }>65 \text { tahun } \\
\mathrm{P}: \text { :Perempuan }\end{array}$ & $\mathrm{L}: \mathrm{Lak}$ \\
\hline & O :Olahraga & $\mathrm{T}$ :Tidak \\
\hline
\end{tabular}


Dari gambar 1 terlihat bahwa responden perempuan usia 18-40 tahun dan tidak melakukan olahraga memiliki skor stres awal yang lebih tinggi yaitu sebesar 85 dibandingkan dengan yang rutin melakukan olahraga seminggu sekali dengan skor stres awal 69, kemudian responden laki-laki cenderung memiliki skor stres awal yang lebih rendah yaitu senilai 53 dibandingkan dengan perempuan dengan skor stres awal 85, responden berusia > 65 tahun yang berolahraga memiliki skor stres awal yang rendah sebesar 20 untuk laki-laki dan 60 untuk perempuan, hal ini disebabkan semakin tua seseorang, akan memiliki emosi yang cenderung stabil dan kestabilan ini berpengaruh pada daya tahan terhadap stres.

\section{Gambaran Umum Sumber Stres}

Cara pandang terhadap kehidupan memiliki arti yang penting bagi kesehatan. Membiasakan berpikir positif memiliki ketahanan kuat terhadap penyakit, sementara jika selalu berpikir negatif akan mengakibatkan tubuh menjadi sakit. Diketahui bahwa cinta, tawa, berbagi emosi serta tindakan positif akan mengerahkan pertahanan alamiah tubuh melawan stres, rasa sakit dan penyakit. Dan kehendak untuk hidup, kemampuan untuk bergembira, dan kepercayaan diri merupaka komponenkomponen yang penting dalam menjaga kesehatan. Hormon penting yang terbentuk dalam tubuh berdasarkan pola pikir adalah adrenalin, noradrenalin, beta endorfin dan enkefalin. Noradrenalin diproduksi di otak ketika cemas atau stres. Ketika merasa takut, adrenalin yang akan muncul. Seseorang dapat menjadi stres jika memiliki perasaan yang tertekan, perasaan tertekan tersebut dapat diakibatkan akibat rasa khawatir yang berlebihan, untuk dapat mengurangi stres yang terjadi dapat dilakukan dengan cara mengenali darimana stres tersebut bermula. Berikut merupakan presentase stres menurut penyebabnya.

Tabel 4 Gambaran Penyebab Stres Secara Keseluruhan (n=63)

\begin{tabular}{llcc}
\hline Riwayat stress & Pria $(\mathrm{n}=9) \%$ & Wanita $(\mathrm{n}=54) \%$ & Jumlah \% \\
\hline Psikologi & 12,70 & 77,78 & 90,48 \\
Penyakit & 1,59 & 7,93 & 9,52 \\
\hline Jumlah & 14,29 & 85,71 & 100 \\
\hline
\end{tabular}

Tabel 4 menunjukkan sebagian besar $(90,84 \%)$ stres yang dialami responden disebabkan oleh adanya tekanan psikologis dan sisanya sebesar 9,52\% penyebab stres karena penyakit. Penyakit berasal dari jiwa, hasil penelitian mengenai hormon beta endorfin menyatakan bahwa pikiran dan emosi berpengaruh kuat terhadap otak. Dapat diasumsikan pikiran dan emosi berlangsung di batang otak, sistem limbik, dan korteks serebrum. Pada bagian otak ini, berlangsung juga proses syaraf A10' yang berhubungan dengan banyak fungsi kognitif dan emosional. Saraf A10' dikenal sebagai saraf perasaan senang, bahagia, dan gairah. Saraf penting ini menghubungkan semua bidang dan fungsi otak satu sama lain, mulai dari kebutuhan fisik yang sederhana seperti libido, nafsu makan, dan pengaturan suhu tubuh, sampai pada mekanisme korteks prefontal yang didalamnya bertempat fungsi kognitif ${ }^{4}$.

Dopamin adalah neurotransmitter yang memainkan peran 
kunci proses pengendalian di otak, ketika sedang bahagia gelombang alfa mendominasi di otak dan beta endorfin juga dikeluarkan dalam jumlah melimpah. Stres berat dapat mengakibatkan munculnya suatu penyakit karena noradrenalin diproduksi dalam jumlah berlebih. Hormon beta endorfin dapat memerangi sel-sel kanker, dan memeperbaiki suasana hati. Sel-sel pembunuh alami bertugas menghancurkan sel-sel kanker, melepaskan perforin, sejenis penghancur membran yang melubangi membran sel kanker. Melalui lubang ini, air dan garam memasuki selsel kanker, menyebabkan kematian sel tersebut dalam beberapa menit. Satu sel NK dapat menghancurkan banyak sel kanker, dimana aktivitas sel NK akan menguat apabila beta endorfin berperan serta. Gangguan psikologis merupakan pemicu timbulnya stress. Adapun gambaran sumber stres yang dikarenakan faktor psikologis, di dapatkan data sebagai berikut.

Tabel 5 Gambaran sumber stres yang disebabkan faktor psikologi $(\mathrm{n}=63)$

\begin{tabular}{lc}
\hline \multicolumn{1}{c}{ Stressor } & Presentase $\%$ \\
\hline Hubungan dengan & 36,84 \\
keluarga & \\
Masa depan & 47,37 \\
Keuangan & 22,81 \\
Pekerjaan & 10,53 \\
\hline
\end{tabular}

Pada Tabel 5 dapat dilihat bahwa sumber stres yang terbesar adalah pemikiran tentang masa depan sebesar $47,37 \%$, kemudian hubungan dengan keluarga 36,84\%, disusul dengan masalah keuangan yaitu sebesar $22,81 \%$ dan yang terakhir adalah masalah pekerjaan sebesar 10,53\%. Kekhawatiran terhadap masa depan dan hubungan dengan keluarga memiliki persentase yang sangat besar hal ini diduga dikarenakan sebagian besar responden adalah wanita dan berprofesi sebagai ibu rumah tangga sehingga yang menjadi kehawatiran mereka adalah meliputi keharmonisan, keutuhan serta kesejahteraan keluarga.

Sumber stresor terberat yang dialami adalah masalah masa depan yakni sebesar 47,37\%. Masalah masa depan dianggap sebagai masalah paling berat, kekhawatiran terhadap masa depan mereka disebabkan oleh masalah keuangan seperti masalah ketiadaan biaya untuk kebutuhan keluarga, pendidikan anak, dan sulitnya mencari lapangan pekerjaan karena tingkat pendidikan yang rendah dan persaingan lapangan pekerjaan yang ketat, karena sebagian besar responden berasal dari keluarga dengan tingkat sosial ekonomi menengah ke bawah $^{11,12}$. Tubuh memiliki mekanisme pengaturan keseimbangan dalam sistem metabolismenya yang dikenal sebagai homeostasis. Mekanisme homeostsis yang terdapat pada semua organisme juga berfungsi pada hormon. Ketika noradrenalin atau adrenalin dilepaskan, seretonin pasti ikut dibebaskan untuk menghambat pengaruh kedua hormon stres tersebut. Reaksi ini dikenal sebagai umpan balik negatif.

\section{Analisis Efektivitas Akupunktur "GI" Terhadap Kasus Stres Terhadap Jenis Kelamin}

Hubungan antara jenis kelamin dengan penurunan skor stres didapatkan dengan menghubungkan jenis kelamin dengan masing masing skor stres setelah mendapat terapi ke-2, 4, hingga 18. $\mathrm{H}_{0}$ diasumsikan tidak terdapat hubungan yang signifikan antara variabel bebas (jenis kelamin) dan variabel terikat (skor stres). 


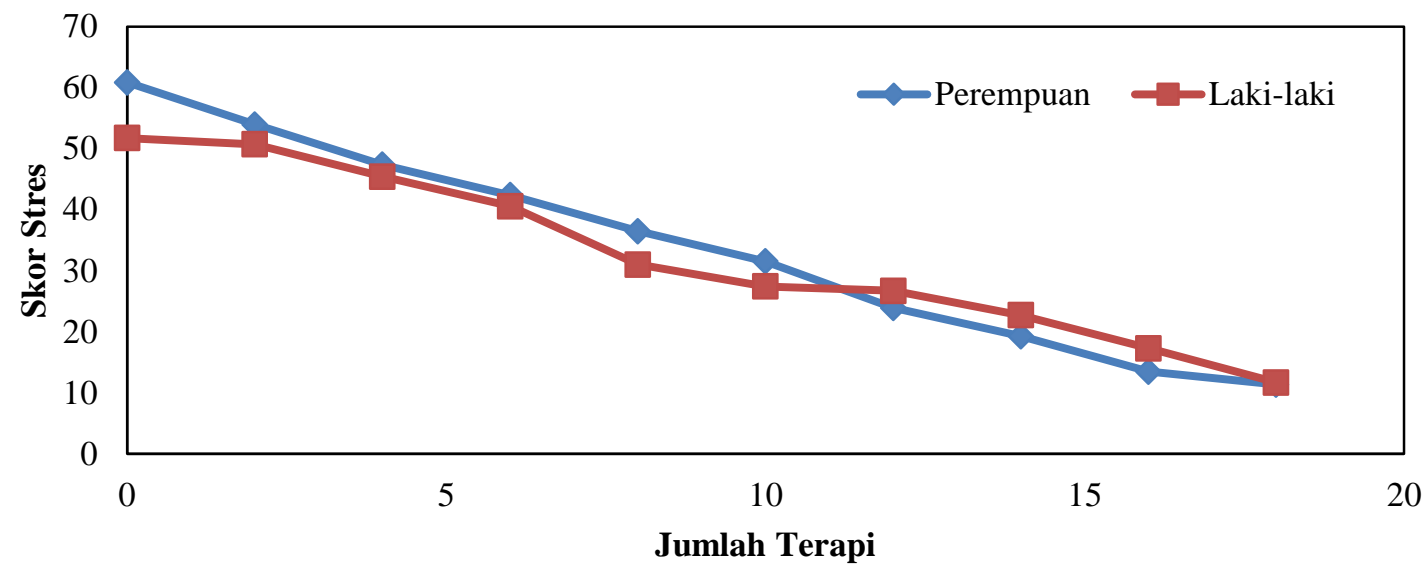

Gambar 2. Rata-rata skor stres Vs Jumlah Akupunktur

Dari hasil uji statistik yang dilakukan untuk melihat hubungan antara jenis kelamin dan penurunan skor stres didapatkan nilai $r=0,673$ menandakan terjadi hubungan yang kuat antara jenis kelamin terhadap tingkat penurunan skor stres, dimana korelasi antara prubahan skor stres dan jumlah terapi dilihat dari parameter jenis kelamin memiliki tingkat hubungan yang kuat yang berarti jenis kelamin mempengaruhi dalam penurunan skor stres, dan dari gambar 5 dapat dilihat bahwa pria cenderung lebih cepat mengalami penurunan skor stres dibandingkan wanita. Jenis kelamin merupakan salah satu faktor resiko pada stres. Dengan demikian dapat disimpulkan, berdasarkan hasil analisis statistik bahwa efektivitas akupunktur "GI" berpengaruh terhadap jenis kelamin, dan H0 ditolak.

\section{Analisis Efektivitas Akupunktur "GI" Terhadap Kasus Stres Terhadap Usia}

Analisis ini dilakukan untuk membuktikan apakah terjadi perbedaan yang terjadi pada efektivitas terapi akupunktur "GI" berdasarkan kelompok usia. Hipotesis nol yang diajukan adalah bahwa tidak terdapat perbedaan bermakna antara penurunan jumlah skor stres terhadap usia.

Usia merupakan salah satu faktor yang berpengaruh terhadap stres individu yang semakin tua akan memiliki emosi yang cenderung semakin stabil dan kestabilan emosi ini memiliki pengaruh terhadap daya tahan terhadap stres. Tapi dapat pula dengan bertambah usia maka kecenderungan untuk mengalami stres akan semakin besar, hal ini berkaitan dengan semakin bertambahnya usia seseorang akan diikuti dengan kemunduran dari faktor fisiologis dalam berbagai kemampuan seperti pendengaran, ingatan, berfikir dan kemampuan visual ${ }^{13}$. 


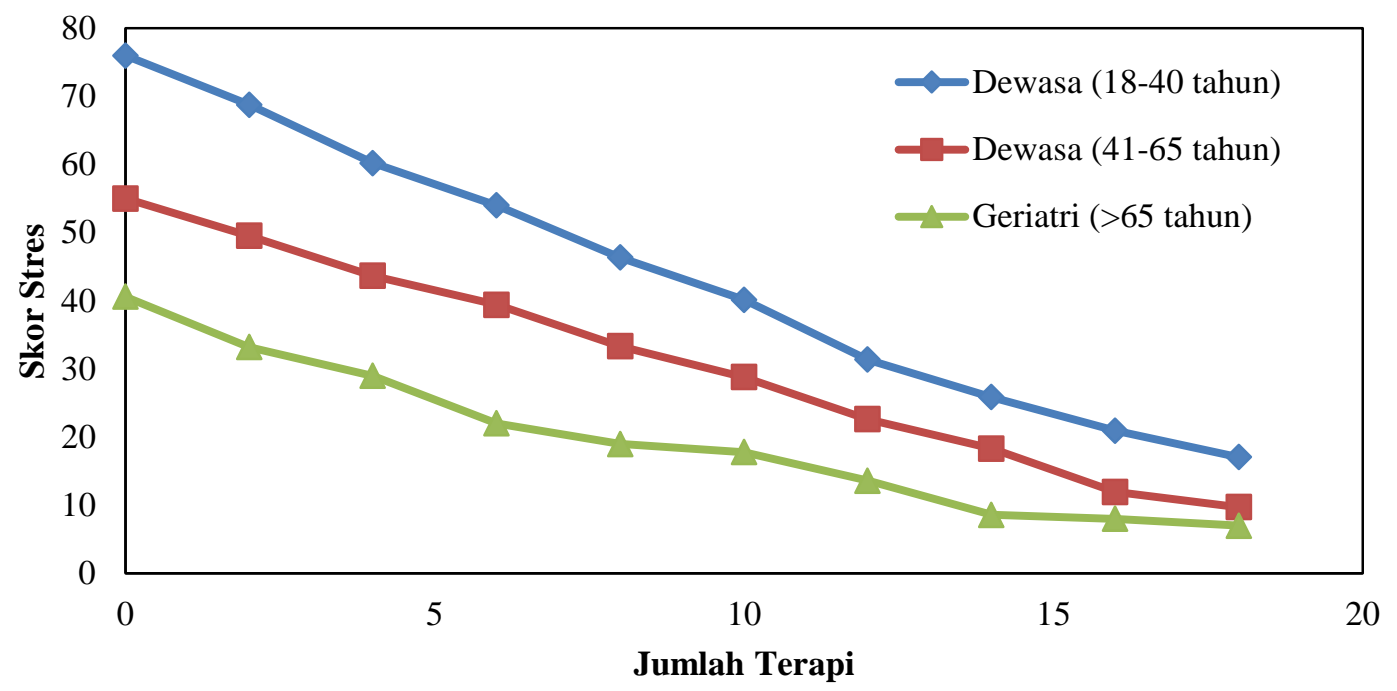

Gambar 3. Rata-rata skor stres vs jumlah akupunktur dari parameter usia

Dari gambar 3 menunjukkan bahwa semakin muda usia seseorang maka daya tahannya terhadap stres semakin lemah, dimana untuk usia 18-40 tahun menduduki tingkat paling atas dengan skor stres awal sebesar 76 dan setelah di terapi sebanyak 18 kali skor stres berada pada skor 17, untuk usia 4065 tahun skor stres awal dimulai pada angka 55 dan setelah 18 kali akupunktur skor stres berada pada angka 9, sedangkan pada usia geriatri ( $>65$ tahun) skor stres awal adalah sebesar 40 dan berakhir di skor 7 setelah menjalani sebanyak 18 kali terapi akupunktur.

Hasil analisis statistik menunjukkan adanya perbedaan yang bermakna antara kelompok sebelum terapi dan sesudah terapi pada kelompok usia 18-40 tahun, 40-65 tahun dan $>65$ tahun. Dan diperoleh nilai $\mathrm{p}<0,05$, berarti hipotesis nol ditolak. untuk melihat hubungan penurunan skor stres terhadap jumlah akupunktur ditinjau dari parameter usia. Didapatkan nilai korelasi sebesar 0,540 yang artinya tingkat hubungan antara penurunan skor stres dengan jumlah akupunktur yang dilihat dari parameter usia adalah sedang, yang berarti semakin banyak responden menjalani terapi akupunktur belum tentu membuat penurunan dari skor stres dimana usia tidak berpengaruh banyak dalam penurunan skor stres.

\section{Kesimpulan}

Berdasarkan hasil penelitian maka dapat diambil beberapa kesimpulan sebagai berikut:

- Adanya perbedaan skor stres antara sebelum dan sesudah akupunktur, dan didapatkannya hubungan antara jumlah akupunktur dengan penurunan skor stres yakni semakin sering terapi akupunktur dilakukan maka skor stres akan semakin menurun, penurunan dari skor stres bermakna terjadinya penurunan tingkatan stres yang dialami responden.

- Terdapat hubungan antara jenis kelamin dengan penurunan skor stres setelah diakupunktur, yakni responden pria cenderung sedikit lebih cepat mengalami penurunan skor stres dibandingkan responden perempuan. 


\section{DAFTAR PUSTAKA}

1. Guan, Y. J., J. J. Xiang, dan Jin L. (2006) : Contemporary Medical Acupuncture- A System Approach, Higher Education Press, Beijing, 277278

2. Ismail, G. (2009) : Sehat Tanpa Obat dengan Tusuk Jarum Ala Indonesia, Grasindo, Jakarta, 40-82

3. World Health Organization, (2002) : Guidelines on Basic Training and safety in Acupuncture, Geneva, 19-20

4. Haruyama, S. (2011): The Miracle of Endorphin, Mizan Pustaka, Bandung. $36-100$

5. Zhang, X,R. (2002) : Acupuncture : Review and Analysis of Reports on Controlled Clinical Trials, World Health Organization ,Geneva, 1,5,17.

6. Lovibond, S.H. \& Lovibond, P.F. (1995) : Manual for the Depression Anxiety Stress Scales, $2^{\text {nd }}$ ed., Psychology Fundation, Sydney.

7. Sunyoto D. dan Ari S. (2013) : Buku Ajar Statisik Kesehatan Parametrik, Non Parametrik, Validitas, dan
Reliabilitas, Nuha Media, Yogyakarta. 309-312

8. Schmeelk-Cone, K. H., dan Zimmerman M.A. (2003): A Longitudinal Analysis Of Stress In African American Youth: Predictors and Outcomes Of Stress Trajeetories. Journaln Of Youth Adolescence., 6 (32), 419-432

9. Levine, B.R. (2006) : Sehat Berawal dari Pikiran. Buana Ilmu Populer, Jakarta, 34 - 97

10. Borysenko, J., (1988) : Minding The Body Mending The Mind. Bantam Books, New York, 13

11. Santrock, J.W. (2003) : Aldocense (perkembangan remaja), Terjemahan oleh Soejarwo. Erlangga., Jakarta

12. Hamid, P. N., Yue X. D., dan Leung, C. M. (2003) : Aldolescent Coping In Different Chinese Family Environments. Journal Of Aldolescent, 38 (149), 111-123

13. Hurlock., (2008) : Psikologi perkembangan suatu pendekatan sepanjang rentang kehidupan, $5^{\text {th }}$ ed., Erlangga, Jakarta. 320-336 